\title{
Construction of Plant Transformation Vectors Carrying Beet Necrotic Yellow Vein Virus Coat Protein Gene (II)- Plant Transformation
}

\section{N. Nagl, I. Atanassov, K. Roussanov, S. Paunovich, A. Atanassov \& L. Kovachev}

To cite this article: N. Nagl, I. Atanassov, K. Roussanov, S. Paunovich, A. Atanassov \& L. Kovachev (2005) Construction of Plant Transformation Vectors Carrying Beet Necrotic Yellow Vein Virus Coat Protein Gene (II)- Plant Transformation, Biotechnology \& Biotechnological Equipment, 19:3, 39-45, DOI: $10.1080 / 13102818.2005 .10817225$

To link to this article: https://doi.org/10.1080/13102818.2005.10817225

\section{(c) 2005 Taylor and Francis Group, LLC}

\section{Published online: 15 Apr 2014.}

Submit your article to this journal $₫$

Џll Article views: 119

Q View related articles $\sqsubset$ 


\title{
CONSTRUCTION OF PLANT TRANSFORMATION VECTORS CARRYING BEET NECROTIC YELLOW VEIN VIRUS COAT PROTEIN GENE (II)- PLANT TRANSFORMATION
}

\author{
N. Nagl ${ }^{1}$, I. Atanassov ${ }^{2}$, K. Roussanov ${ }^{2}$, S. Paunovich ${ }^{3}$, A. Atanassov ${ }^{2}$, L. Kovachev ${ }^{1}$ \\ Institute of Field and Vegetable Cops, Novi Sad, Serbia and Montenegro ${ }^{1}$ \\ AgroBioInstitute, Sofia, Bulgaria ${ }^{2}$ \\ Center for Fruit Growing and Viticulture, Chachak, Serbia and Montenegro ${ }^{3}$
}

\begin{abstract}
Fragments containing the coat protein gene of beet necrotic yellow vein virus were cloned in two plant transformation vectors: pCAMBIA3301M with the bar gene as selectable marker, and pCAMBIA1304M, with resistance to hygromycin. Three constructs were made of each vector: CPL, containing coat protein gene with leader sequence; CPS with coat protein gene, and CPSas with coat protein gene in antisense orientation. Vectors pC3301MCPL, pC3301MCPS. and pC3301MCPSas were used in Agrobacterium mediated transformation of Nicotiana tabacum (tobacco), Nicotiana excelsior and Nicotiana benthamiana. Regenerants that developed roots on selective media were tested for the presence of CP fragments and the bar gene, but most regenerants were nontransformed (50-83\% escapes). After all rooted plants had been selfed, and T1 seed germinated on selective media, only plants descending from one N. excelsior regenerant transformed with pC3301MCPS were positive for presence of bar gene and CPS fragment. Tobacco and Nicotiana benthamiana were transformed with constructs pC1304MCPS and pC1304MCPSas. Transformation efficiency was much higher and approximately 50\% of regenerants that rooted on media with $20 \mathrm{mg} \mathrm{l}^{-1}$ hygromycin were positive for the presence of CP fragments. All $T_{1}$ plants were positive for presence of CP fragments.
\end{abstract}

\section{Introduction}

Rhizomania is the most important disease of sugar beet (Beta vulgaris L.) wordwide, caused by beet necrotic yellow vein virus (BNYVV) (32). Rhizomania is characterized by massive lateral proliferation of rootlets, constriction of the main taproot and a necrosis of vascular tissue, which leads to reduction of root yield up to $90 \%$, while sugar content and processing quality can be badly affected as well. This virus is transmitted by soil-borne fungus Polymyxa betae, which is known to be able to survive in the soil for more than five years in the form of very robust resting spores (6).
Since agonomical and agrochemical management of rhizomania infested soil is inefficient, the most hopeful aspect of rhizomania control is breeding for resistance (1). Most of rhizomania tolerant genotypes, that perform very good in the conditions of mild infection, have one of the following types of resistance (11, 29): "Rhizor", "Holly", or resistance deriving from crosses with Beta vulgaris subsp. maritima. However, since genotypes with different degrees and types of resistance vary in their response to different BNYVV strains, climatic and soil conditions (14) many sugar beet breeding programs are now directed 
towards combining known sources of resistance and introducing thenew ones, including transgenic resistance.

There were few reports about inducing of transgenic resistance to rhizomania in sugar beet, by introducing the BNYVV coat protein gene ( $\mathrm{CP}$ gene). Transformation of protoplasts with BNYVV CP gene was achieved by 17 but no transformed plant could be regenerated. The similar results were obtained with $A$. rhizogenes transformation, where many transformed hairy roots were formed, but none of them regenerated transgenic plant (9). Successful transformation was reported by 23 where transgenic sugar beet, plants were obtained after Agrobacterium transformation with constructs containing BNYVV coat protein gene and coat protein gene with leader sequence.

A possible reason for so few reports with successful sugar beet transformation is the fact that it has been very recalcitrant to regeneration after transformation with $A$. $t u$ mefaciens, although the bacteria is able to inoculate the plant tissue (20). No matter what type of explant was used $(16,21,34)$, the induction of transgenic plants was very low and strongly dependant on genotype or binary vector. Particle bombardment of apical meristem (22), cell suspension (15) and embryogenic callus (31) did not give better results. The only transformation method that gave stable results regardless of genotype or vector is PEG transformation of stomatal guard cells protoplasts (12, 30 ), but this method is technically demanding and expensive.

In order to test ability of constructed plant transformation vectors to incorporate their T-DNAs in plant genome, we used them for transformation of some model plants. In the paper are presented results of tobacco, Nicotiana excelsior and Nicotiana benthamiana transformation with binary vectors containing BNYVV coat protein gene in sense or antisense orientation, with and without leader sequence.

\section{Materials and Methods}

\section{Binary vectors}

For plant transformation was used Agrobacterium tumefaciens strain LBA 4404 carrying binary vectors pCAMBIA3301M and pCAMBIA1304M. The coding sequences of BNYVV coat protein gene were isolated as 731 bp (CPL), and $587 \mathrm{bp}$ (CPS) cDNAs, and cloned in plant transformation vectors pCAMBIA3301M and pCAMBIA1304M. Three constructs were obtained from each vector: CPL, CPS and CPSas, with the coat protein gene in antisense orientation.

In all constructs (Fig. 1), the coat protein gene was driven by the cauliflower mosaic virus promoter (35S) and followed by 3' nopalin synthase (nos) terminator. As selectable marker, constructs deriving from vector pCAMBIA3301M contained bar gene conferring resistance to herbicide phosphinotricin, while constructs deriving from pCAMBIA1304M had gene for resistance to hygromycin $(h y g)$. Selectable markers were driven by the $35 \mathrm{~S}$ promoter and followed by $35 \mathrm{~S}$ polyA.

\section{Plant transformation}

Tobacco and Nicotiana excelsior were transformed with A. tumefaciens carrying pC3301MCPL, pC3301MCPS, and pC3301MCPSas, while tobacco and Nicotiana bethamiana were transformed by A. tumefaciens carrying pC1304MCPS and pC1304MCPSas. All transformations were done following slightly modified leaf disc transformation method (13): cells of $A$. tumefaciens were grown on a rotary shaker, at $28^{\circ} \mathrm{C}$ in $20 \mathrm{ml} \mathrm{NB}$ medium for $24 \mathrm{~h}$. The medium contained $100 \mu \mathrm{g} / \mathrm{ml}$ of rifampicin and $50 \mu \mathrm{g} / \mathrm{ml}$ kanamycin, or $100 \mu \mathrm{g} / \mathrm{ml}$ rifampicin and $20 \mu \mathrm{g} / \mathrm{ml}$ hygromycin. The overnight cultures were centrifuged at 3000 $\mathrm{rpm}$ at $4^{\circ} \mathrm{C}$ and resuspended in $2 \mathrm{ml}$ of MS (26) medium. The leaves were cut into pieces of $1 \mathrm{~cm}^{2}$ size, submerged in $10 \mathrm{ml}$ MS medium with $2 \mathrm{mg} \mathrm{l}^{-1} \mathrm{BAP}$ and $0.2 \mathrm{mg}$ $\mathrm{1}^{-1}$ IAA, in which was dissolved $600 \mu \mathrm{l}$ of A. tumefaciens suspension and left for 30 
$\begin{array}{lll}\text { Left border } & \text { Right border }\end{array}$

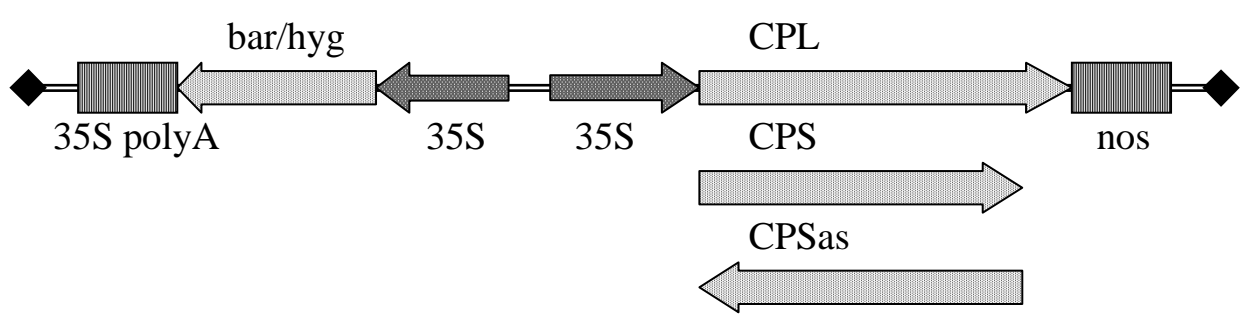

Fig. 1. T-DNA of plant transformation vectors pC3301MCP/pC1304MCP.

min. The explants were then transferred on solid MSD medium and left on cocultivation, at $21^{\circ} \mathrm{C}$ in the dark for three days. After cocultivation, the explants were washed, blotted dry and put on MSD medium with $500 \mathrm{mg} \mathrm{l}^{-1}$ cefotaxime. Selective media for explants transformed with $\mathrm{pC} 3301 \mathrm{MCP}$ vectors also contained 5 $\mathrm{mg} \mathrm{1}^{-1}$ phosphinotricin (DUCHEFA, Holland), while those for explants transformed with $1304 \mathrm{MCP}$ vectors had 20 $\mathrm{mg} \mathrm{l}^{-1}$ hygromycin. All regenerants were transferred on solid MS medium with 500 $\mathrm{mg} \quad \mathrm{l}^{-1}$ cefotaxime and $5 \mathrm{mg} \mathrm{l}^{-1}$ phosphinotricin, i.e. $20 \mathrm{mg} \mathrm{l}^{-1}$ hygromycin. Detection of transgenic plants

Regenerants of tobacco, $N$. excelsior and $N$. benthamiana that developed roots on selective media, were tested for the presence of bar gene and CP fragments.

Isolation of DNA was carried out as described in 27, and $30-50 \mathrm{ng}$ was used in PCR reactions with specific primers. PCR was performed in $25 \mu \mathrm{l}$ volume with $1 \mathrm{x}$ PCR buffer, $1.5 \mathrm{mM} \mathrm{MgCl} 2,2 \mathrm{mM}$ of dNTP, 2 units Taq polymerase (Amersham Pharmacia Biotech) and 100pM of each primer. For detection of bar gene specific primers were used: BARf (5'AGCCGCAGGAACCGCAGGAGTG3') and BARr (5'ATGCCAGTTCCCGTGCTTGA AG3') giving 362 bp PCR product. Specific primers were made to complement the coat protein gene on BNYVV (3): two 5' primers P1 (5'CGAGATCTAAATTCTAACTATTATCTCC3') and P2 (5'GTAGA-
TCTATGTCGAGTGAAGGTAG3'), and one 3' primer P3 (5'CCGATA TCCAGCTAATTGCTATTGT C3'). For detection of transgenic plants, primers specific for 35S promotor (5'AAACCTCCTCGGATTCCATTG3') and nos terminator (CCATCTCAT AAATAACGTCATGCAT) were used as well. Thermocycling was carried out as follows, $94^{\circ} \mathrm{C}, 5 \mathrm{~min}$., then 35 cycles of $92^{\circ} \mathrm{C}$ for 30 s., $50.5,56$ or $57^{\circ} \mathrm{C}$ (depending of prmer combination) for 1 min., $72^{\circ} \mathrm{C}$ for $1 \mathrm{~min}$., followed by $72^{\circ} \mathrm{C}$ for $6 \mathrm{~min}$.

Plants of tobacco, $N$. excelsior and $N$. benthamiana positive for presence of coat protein gene or bar gene were grown in the chamber, on $22 \pm 1^{\circ} \mathrm{C}$ and photoperiod 16/8h until flowering, when self pollination was done. Seeds of T1 generation were sterilized and germinated on selective MS media with $5 \mathrm{mg} \mathrm{l}^{-1}$ phosphinotricin or 20 $\mathrm{mg} \mathrm{l}^{-1}$ hygromycin. T1 plants that developed on selective media were analyzed for presence of coat protein gene or bar gene following described PCR protocol.

\section{Results and Discussion}

\section{Transformation of tobacco and} N. excelsior with pC3301MCP constructs Seven days after inoculation with Agrobacterium, all explants showed tissue proliferation and after two weeks the first organogenic buds could be observed (Fig. 2). Well developed regenerants were transferred on selective MS medium for rhizogenesis. After 7-14 days some regene- 


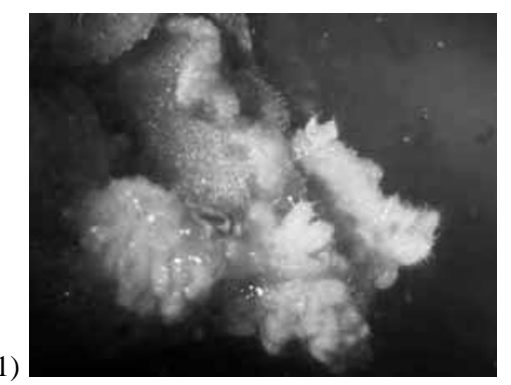

Fig. 2. Organogenesis on transformed leaf explant.

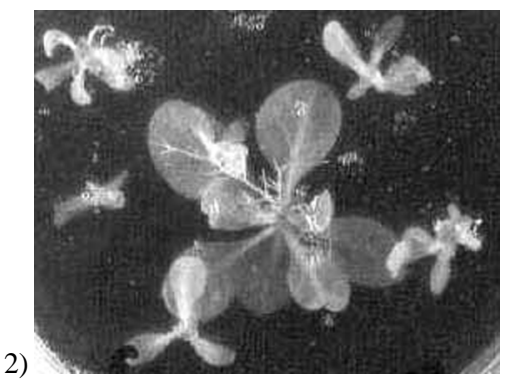

Fig 3. Rhizogenesis of regenerants on selective medium.
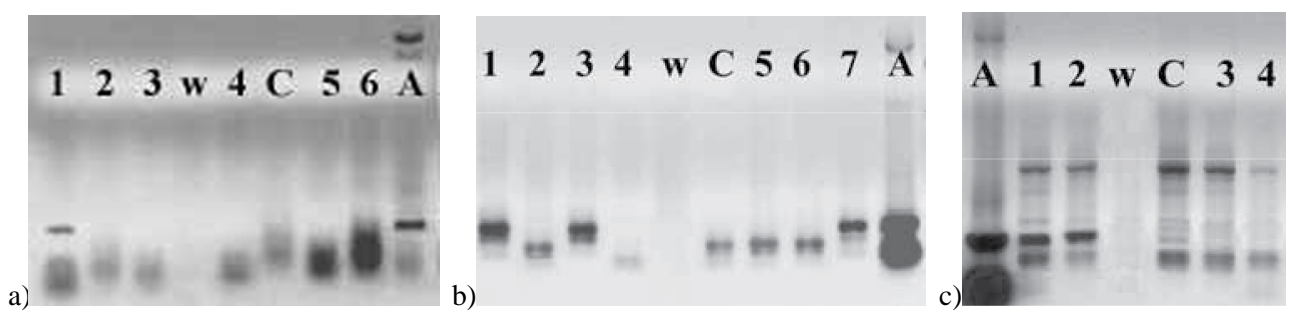

Fig. 4. Detection of bar gene in regenerants rooted in selective medium: a) $N$. excelsior after transformation with pC3301MCPL (1-6 - regenerants, w - water, C - control plant, A - pC3301MCPL), b) N. excelsior after transformation with pC3301MCPS (1-7 - regenerants, w - water, C - control plant, A - pC3301MCPS) c) tobacco after transformation with pC3301MCPSas ( 1-4 - regenerants, w - water, C - control plant, A pC3301MCPS).

rants developed roots on selective media (Fig. 3): $21.4 \%$ of $N$. excelsior regenerants transformed with pC3301MCPL, and $23.6 \%$ after transformation with pC3301MCPS. After transformation with pC3301MCPSas, $26.9 \%$ of tobacco regenerants developed roots on selective medium.

PCR analysis of rooted regenerants for presence of $\mathrm{CP}$ fragments did not give consistent results, but PCR detection of bar gene showed that some $N$. excelsior regenerants transformed with pC3301MCPL (Fig. 4a) and pC3301MCPS (Fig. 4b) were bar positive, while only four out of six rooted tobacco regenerants developed enough to be micropropagated, and two of them were bar positive (Fig. 4c).

All regenerants that developed roots on selective medium were transferred to pots and grown until flowering and self pollination. Seed of T1 generation was put on the medium with phosphinotricin and only those deriving from one $N$. excelsior plant, transformed with pC3301MCPS construct, had germination over $90 \%$. They developed into the plants that, compared to non transformed, showed no morphological differences (Fig. 5a). All T1 plants were positive for presence of both, bar gene and CPS fragment (Fig. 5b,5c).

\section{Transformation of tobacco and}

\section{N. benthamiana with pC1304MCP} constructs

After transformation with pC1304MCPS and pC1304MCPSas, explants of tobacco and $N$. benthamiana developed in the same way as those transformed with pC3301MCP constructs. After transformation with pC1304MCPS, 53\% of $N$. benthamiana regenerants gave root on the selective medium, while after transformation with pC1304MCPSas rhizogenesis occurred in $70 \%$ of tobacco regenerants. One regenerant of $N$. benthamiana and four regenerants of tobacco that were positive 

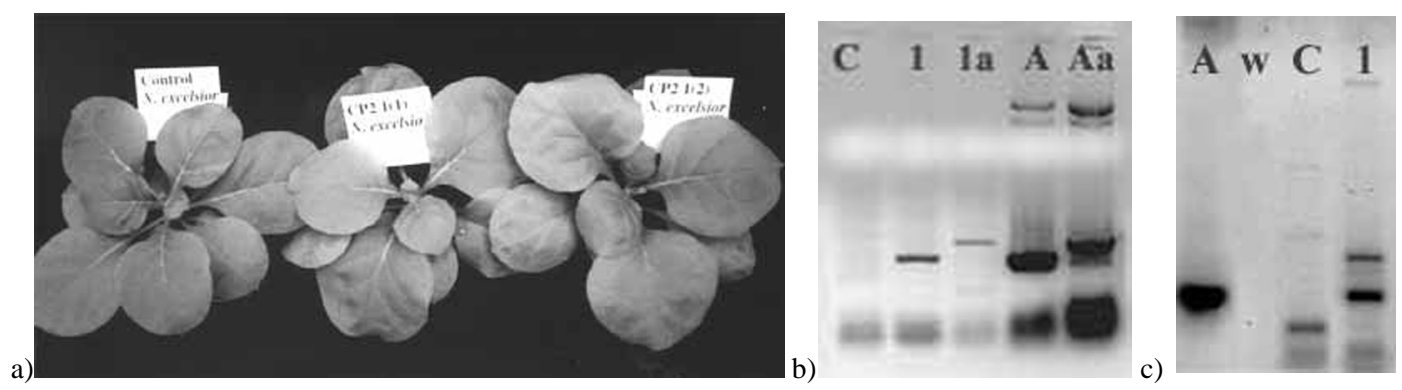

Fig. 5. T1 plants of $N$. excelsior: a) morphology (control is left), b) detection of CPS (C - control; 1 transgenic plant/P2+P3; 1a - transgenic plant/P2+NOSrev; A - pC3301MCPS/P2+P3; Aa - pC3301MCPS/ P2+NOSrev), c) detection of bar gene (A - pC3301MCPS; w - water; C - control; 1 - transgenic plant).

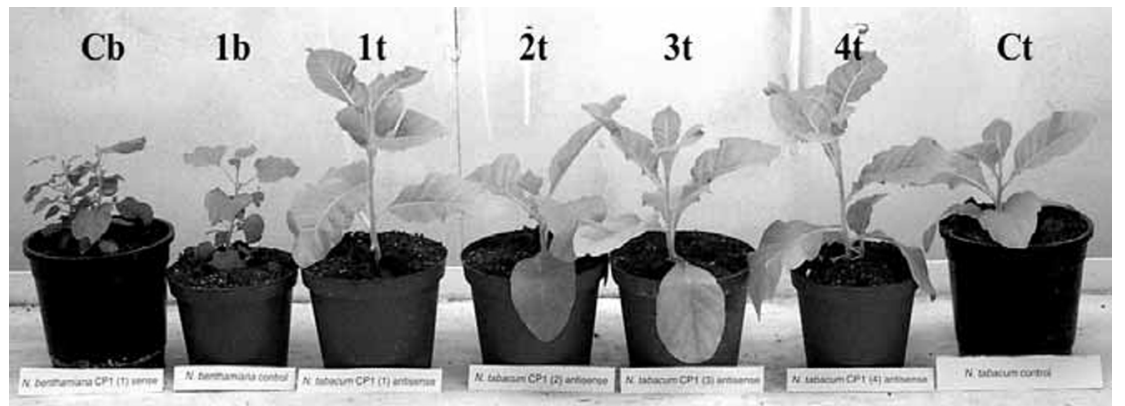

Fig. 6. T1 plants of $N$. benthamiana and tobacco, transformaed with pC1304MCPS and pC1304MCPSas $(\mathrm{Cb}-$ $\mathrm{N}$. benthamiana control plant, $1 \mathrm{~b}-N$. benthamiana transformed with CPS, 1t,2t - tobacco transformed with CPS, 3t,4t - tobacco transformed with CPSas, $\mathrm{Ct}$ - tobacco control plant).

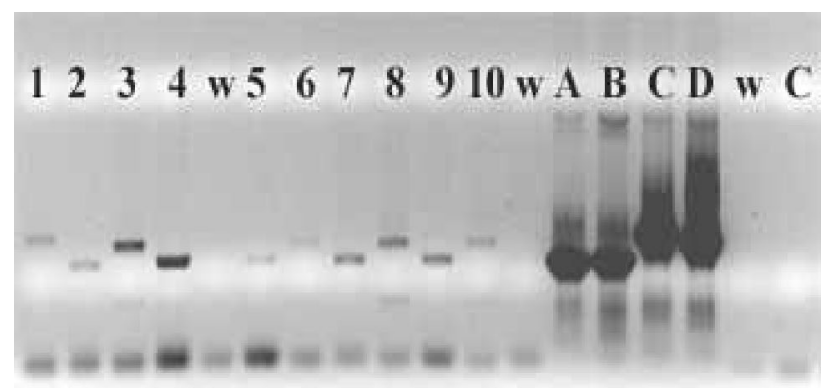

Fig. 7. Detection of CPS and CPSas fragments in tobacco and $N$. benthamiana plants $(1-\mathrm{N}$. benthamiana/35Sfw $+\mathrm{P} 3,2-\mathrm{N}$. benthamiana/P2+P3, 3 - tobacco/35Sfw+P3, $4-$ tobacco/ $\mathrm{P} 2+\mathrm{P} 3$, w - water, 5, 7, $9-$ tobacco/P2+P3, 6, 8, 10 - tobacco/P3+NOSrev, A - pC1304MCPS/ P2+P3, B - pC1304MCPSas/P2+P3, C pC1304MCPS/35Sfw+P3, pC1304MCPSas/P3+ NOSrev, C - control plant/P2+P3).

for presence of coat protein gene, were transferred to the pots and grown until flowering, when the self pollination was done. Seed deriving from all $\mathrm{CP}$ positive tobacco and $N$. benthamiana plants had over $90 \%$ germination on medium with hygromycin and developed into the plants normal morphological characteristics (Fig. 6). All plants were positive for the presence of CPS fragment in sense or antisense orientation (Fig. 7).

After inoculation of tobacco and N. ex- 
celsior with A. tumefaciens carrying pC3301MCP constructs, resistance to gluphosinate ammonium seemed to be the most stringent selectable marker, allowing growth and rhizogenesis of 14\%, 21.5\% and $19.4 \%$ after transformation with CPL, CPS and CPSas constructs respectively. Nevertheless, the amount of escapes was rather high (83\% for CPL, $57 \%$ for CPS and $50 \%$ for CPSas), confirming the fact that efficiency of this marker differs from case to case $(18,28,33)$. Percent of transformation for all three constructs was under $1 \%$, which indicates that incorporation of T-DNA in plant genome was difficult. At first it was presumed that vector was somehow damaged during modification or cloning of CP fragment, but transformation efficiency of original pCAMBIA3301 on model systems was also extremely low (unpublished data). Probably this vector demands further modifications of transformation protocols, which would be in agreement with results of 5 who determined that transformation efficiency with pC3301 strongly depends on transformation protocol.

Over $60 \%$ of regenerants that developed after transformation with pC1304MCPS and pC1304MCPSas gave roots on medium with hygromycin and the number of escapes was under $50 \%$ fro both vector. This results, as well as the fact that that all $\mathrm{T} 1$ plants deriving from $\mathrm{CP}$ positive regenerants were transformed, indicates that hygromycin is highly reliable selectable marker for Nicotiana species $(7,28)$. Its efficiency could be improved by use of high amounts of hygromycin in first subcultivations $(2,24)$, or by gradually increasing its concentration during micropropagation (19).

One of possibilities to improve transformation efficiency could also be construction of transformation vector with both bar and hyg gene (4) which would further improve hygromycin resistance with additional bar selection. The other option is to use some of the methods for removal of an unfavorable hyg marker and combination with positive bar marker $(8,10.25)$

\section{REFERENCES}

1. Amiri R., Moghaddam M., Mesbah M., Sadeghian S.Y., Ghannadha M.R., Izadpanah K. (2003) Euphytica, 132, 363-373.

2. Aoki T., Kamizawa A., Ayabe S. (2002) Plant Cell Rep., 21, 238-243.

3. Bouzooubaa S., Ziegler V., Beck H., Guilley H., Richards K., Jonard G. (1986) J. Gen. Virol., 67, 1689-1700

4. Chen W.P., Punja Z.K. (2002) Plant Cell Reports, 20, 929-935.

5. Curtis I.S., Nam H.G. (2001) Transgenic Res., 10, 363-371.

6. Dahm H., Buchenauer H. (1993) J. Phytopathology, 139, 329-338.

7. Day A.G., Bejarano E.R., Buck K.W., Burrell M., Lichtenstein C.P. (1991) Proc. Natl. Acad. Sci. USA, 88, 6721-6725.

8. Ebinuma H., Sugita K., Matsunaga E., Endo S., Yamada K., Komamine A. (2001) Plant Cell Rep., 21, 383-392.

9. Ehlers U., Commandeur U., Frank R., Landsmann J., Koenig R., Burgermeister W. (1991) Theor. Appl. Genet., 81, 777-782.

10. Francois I., Broekaert W., Cammue B. (2002) Plant Sci., 163, 281-295.

11. Geyl L., Garcia Heriz M., Valentin P., Hehn A., Merdinoglu D. (1995) Plant Pathology, 44, 819828 .

12. Hall R.D., Riksen-Bruinsma T., Weyens G.J., Rosquin I.J., Denys P.N., Evans I.J., Lathouwers J.E., Lefebvre M.C., Dunwell J.M., vanTunnen A., Krens F.A. (1996) Nature Biotechnol., 14, 11331138

13. Horsch R.B., Fry J.E., Hoffmann N.L., Eichholtz D., Rogers S.G., Fraley R.T. (1985) Science, 227, 1229-1231.

14. Heijbroek W., Mustersa P.M.S., Schoone A.H.L. (1999) Eur. J. Plant Pathol., 105, 397-405.

15. Ingersoll J.C., Heutte T.M., Owen L.D. (1996) Plant Cell Rep., 15(11), 836-840.

16. Jacq B., Lesobre O., Sangwan R.S., SangwanNorreel B.S. (1993) Plant Cell Rep., 12, 621-624.

17. Kallerhoff J., Perez P., Bouzoubaa S., Ben Tahar S., Perret J. (1990) Plant Cell Rep., 9, 224228.

18. Khanna H.K., Raina S.K., Kumar S., Kumar K. (1997) J. Plant Biochem. Biotechnol., 6, 75-80. 
19. Kondo T., Hasegawa H., Suzuki M. (2000) Plant Cell Rep., 19, 989-993.

20. Krens F.A., Zijlstra C., v.d. Molen W., Jamar D., Huizing H.J. (1988) Euphytica, 40, 185-194.

21. Krens F.A., Trifonova A., Keizer L.C.P., Hall R.D. (1996) Plant Sci., 116, 97-106.

22. Mahn A., Matzk A., Sautter C., Schiemann J. (1995) J. Exp. Bot., 46(291), 1625-1628.

23. Mannerloef M., Lennerfors B.-L., Tenning P. (1996) Euphytica, 90, 293-299.

24. Men S., Ming X., Wang Y., Liu R., Wei C., Li Y. (2002) Plant Cell Rep., 4, 552-559.

25. Mihalka V., Balasy E., Nagy I. (2003) Plant Cell Rep., 21, 778-784.

26. Murashige T., Skoog F. (1962) Physiol. Plant., 15, 473-497.

27. Murray M.G., Thompson W.F. (1980) Nucleic Acids Res., 8, 4321-4325.

28. Park S.H., Rose S.C., Zapata C., Srivatanakul
M., Smith R.H. (1998) In Vitro Cell. Dev. Biol. Plant, 34, 117-121.

29. Scholten O.E., Lange W. (2000) Euphytica, 112, 219-231.

30. Sevenier R., Hall R.D., v.d.Meer I.M., Hakkert H.J.C., v.Tunen A.J., Koops A.J. (1998)

Nature Biotech., 16, 843-846.

31. Snyder G.W., Ingersoll J.C., Smigocki A.C., Owens L.D. (1999) Plant Cell Rep., 18, 829-834.

32. Tamada T. (1975) CMI/AAB Descriptions of Plant Viruses, 144, p. 4.

33. Valkov V.T., Bachvarova R.B., Slavov S.B., Atanassova S.I., Atanassov A.I. (1998) Bulgarian J. Agricult. Sci., 4, 1-7.

34. Zhang C.-L., Chen D.-F., Kubis S., McCormac A., Kubalakova M., Zhang J., Bao M.-Z., Scott N.W., Slater A., Heslop-Harrison J.S., Elliot M.C. (1998) Proc. 61th IIRB Congress, Brussels, Belgium, 381-389. 